DOI: 10.26693/jmbs05.06.066

UDC 612.12-001.45:340.624

Kozlova Yu. V., Kosharnij A. V., Korzachenko M. A., Kytova I. V.

\title{
Retrospective Analysis and Current State of Experimental Models
} of Blast-induced Trauma

\author{
State Institution "Dnipropetrovsk Medical Academy of the Ministry of Health of Ukraine", \\ Dnipro, Ukraine \\ tanatholog@i.ua
}

Combat pathology, particularly mine-blast injury is the main cause of military casualties. In our country, as a factor of destabilization, are widely used terrorist attacks using explosive devices of different capacities. Blast injury over $60 \%$ is cause of military casualties during armed conflicts. It is known that the condition for the formation of air-shock wave is creating waves of pressure, which is distributed at supersonic speed as possible with pulsed gas explosion and expansion of compression ambient air. The brain, chest, abdomen, and bladder are the most sensitive parts of the human body to blast. But the pathogenesis, diagnosis, treatment and rehabilitation of post-traumatic explosion-induced disorders, namely, neurodegenerative complications psychosomatic, cognitive impairment, currently not fully understood and are not clear enough for an adequate therapy.

The purpose of the study was to analyze the advantages and disadvantages of experimental models of blast-induced injury and to improve method and compressed air-driven shock tube.

Material and methods. We used the following methods: analysis and evaluation of experimental models of explosion-induced injury by scientific publications, monographs and invention obtained in stages patent information search in the library collection of the State institution "Dnipropetrovsk Medical Academy of the Ministry of Health of Ukraine" (October 2019), a retrospective search of the literature database PubMed (February 2020).

Results and discussion. A retrospective analysis of the number of literary sources on the experimental reproduction of explosive trauma has shown a high interest of a large circle of scientists in the last decade. A qualitative study of scientific publications has shown a wide range of physical characteristics of an experimental shock wave, methods and devices for simulating an explosive injury. The absence of a standardized model of explosive injury with characteristics as close as possible to real circumstances creates conditions for the implementation of our own proposals.

Conclusion. This work presents a tested modified experimental model for reproducing an air shock wave under laboratory conditions, which makes it possible to study the features of the course of an explosive injury of various organs and organ systems at various periods after injury.
Keywords: blast-induced injury, shock tube, experimental model.

Research relation to the programs, plans, and department themes. This study was carried out within the research of the Department of Pathological Physiology of the State Medical Academy "Study of the mechanisms of central nervous system disorders under extreme factors, including on the background of heavy metal intoxication", the state registration number is 0118 U001276.

Introduction. Combat pathology, particularly mine-blast injury is the main cause of military casualties $[1,2,3,4,5]$. In our country, as a factor of destabilization, are widely used terrorist attacks using explosive devices of different capacities. Blast injury over $60 \%$ is cause of military casualties during armed conflicts [6]. In turn, explosive wave, known for spectacular explosion factor, including cumulative effect of several factors, including air-shock wave (ASW) is one of the main factors of initial explosion. Its effect on human was poorly studied [7]. The problem is difficulty visualizing interactions between ASW and biological objects. It is known that the condition for the formation of ASW is creating waves of pressure, which is distributed at supersonic speed as possible with pulsed gas explosion and expansion of compression ambient air [8]. Most sensitive to blast in the human body is the brain, chest and abdomen, bladder [9]. But the pathogenesis, diagnosis, treatment and rehabilitation of post-traumatic explosion-induced disorders, namely, neurodegenerative complications psychosomatic, cognitive impairment, currently not fully understood and are not clear enough for an adequate therapy [10]. Despite recent advances in identifying the key mechanisms of neurological deficits after exposure factors blast, modern diagnostic and treatment strategies require new fundamental knowledge about the mechanisms of explosion-induced injury [11]. It is known that clinical trials of pharmacological agents of influence in experimental pathology, is progress in the development of the healthcare industry and the results of treatment, but they are based on the general principles cerebral protection without specific pathogenic effect.

Thus, for a comprehensive understanding of the biological effects of factors blast, mechanisms of 
injury, the study of neuroendocrine and behavioral changes, time-dependent post-traumatic disorders creation of reliable experimental models of playback according to the actual conditions of the shock is immediate problem [12]. Existing data on the pathology induced explosion conditions are often controversial, due primarily to the use of preclinical studies in different species of animals as well as experimental models $[13,14,15]$.

Due to the large number of clinically established remote complications at this time there is an urgent problem understanding the causes of development, namely, the mechanism of brain trauma [16], stress disorders, heterotopic ossification etc. Taking into account the inexplicability pathogenic mechanisms, post explosive consequences of being an international scientific community is making great efforts to study this problem. One of the essential aspects is playing and simulation of biological factors in the explosion object in tightly controlled laboratory conditions [17, 18, 19].

The purpose of the study was analyzing the advantages and disadvantages of experimental models of blast-induced injury and improve method and compressed air-driven shock tube.

The material analysis and evaluation of experimental models of explosion-induced injury by scientific publications, monographs and invention obtained in stages patent information search in the library collection of the State institution "Dnipropetrovsk Medical Academy of the Ministry of Health of Ukraine" (October 2019), a retrospective search of the literature database PubMed (February 2020).

Results and Discussion. The results are presented as two units. The first unit presents an analysis of existing experimental models of explosion-induced injury with their advantages and disadvantages; the second contains a developed and modified device for generating air shock wave in the experiment describing the experience of its usage in the laboratory.

Depending on the goals pursued by the researcher in modeling the impact of adverse factors of the explosion on the body of experimental animals, the algorithm experiment should be pre-planned, wellbuilt procedure defined location (environment) experiment, method and apparatus for the generation of pathogenic factors, timing and duration experiment, species, age and sex of animals, means of control and quantify the physical, chemical and other characteristics of the factor (s) explosion, exploring.

The basic requirement for an experimental model of explosion-induced injury is a single or repeated act pathogenic factor that will play back the most natural abnormal phase in animals that occur in real clinical situations. In addition, the result set physiological, morphological, biochemical or other methods of re- search should be linked to the action of harmful components explosion [20].

To meet the foregoing requirements of the experiment we conducted a retrospective analysis of selected literature search in PubMed between 1987 and 2019 at the following links: [(((rodent or rat) or mouse) or mice)) and ((blast injury trauma) and (model))))]. On 13 February 2020 the database was presented 242 scientific publications. 218 papers for this search was in the period from 2011 to 2019 (90\%). The greatest activity was recorded in 2018 when there were 34 scientific publications (nearly 14\%). Thus, it is clear that the issue of experimental simulation of blast injury has a long history, but during the last decade, these studies are gaining importance every year.

There is evidence of harmful factors research on biological objects of explosion, since the period of the First World War. The first experimental studies were conducted in an open landfill using artificial explosive devices, as well as biological objects using large animals, such as, primates, pigs, rabbits. Depending on the power of the explosion animals died due to lung or blood loss. However, the experiments did not give any idea of the pathogenesis of non-fatal injuries in an explosion. But researchers were close to understanding effects of the explosion on the body and differentiation mechanisms of harmful factors blast into primary, secondary, tertiary and quaternary effects [21].

Analysis of selected scientific sources showed that research explosion-induced injury with different methodologies, which differed on a number of attributes, namely, a way to generate (playback) of explosive or shock wave devices that are used for this purpose, the position (location) of experimental animals at the time action harmful factor range pressure, etc. $[22,23,24]$.

There are two ways by the method of reproduction or explosive shock wave. The first method is reproduced using a detonation of explosives in an open landfill [25] and in special devices, explosives chamber or shock tube. The second way generates shock waves Play destruction of the diaphragm, which separates the gas or air mixture at high pressure from a biological object. The advantages of the first method is that the circumstances are closer to the real situation with influence of the explosion hazards. Moreover, these conditions may involve both large group of animals with different distances from the epicenter and equipment. But a study in the open space (landfill) has significant drawbacks due to the fact that biological objects are several factors damaging explosion (simultaneous action of the blast wave, thermal, chemical, and other factors), which prevents the investigation of individual exposure or explosive shock wave in the dynamics of post-traumatic period. We should also add that the explosion affects the whole 
body of the subject, leading to high mortality of animals because of pulmonary barotrauma and this prevents further traced, in particular, reactive changes of the central nervous system at different times traumatic period. There were some limitations, which significantly hinder the widespread use of this method. To conduct the experiment, one should get special permission of researchers and relevant services for using explosives requiring special equipment. The second way of generating explosive or shock can eliminate the rest deficiencies due to changes in methodology of reproduction model state by destruction of the diaphragm in a special unit high pressure gas or air mixture and a local impact on the appropriate part of the body. The drawback of this method is that it has great impact or shock waves on biological objects as many researchers state.

The use of explosives in the blast playing in the lab using a shock tube is not only costly but also dangerous. Despite this, the shock tube is an alternative device for generating explosive or shock wave in the experiment. At this time the shock tube is recognized and standard unit for studying the effects of harmful factors, namely, the shock waves on biological objects. Shock tube, depending on the design, can be oriented horizontally or vertically, open or closed muzzle. On the closed end shock tube was used to study the thermodynamic properties of the blast wave. At the same time, the shock tube open end has a wide range of characteristics for research ASW in the experiment.

During the experiment using a shock tube thing is the location of laboratory animals. Currently known is a modern experimental device for the study of the impact on the organism of the shock wave of the explosion, which consists of means of simulating the impact of explosive factors and means of placing experimental animals in the area of action of the explosive factors of the explosion [10]. Modeling tools damaging factors include the explosion shock tube consisting of a camera, high and low pressure separated damaging the diaphragm. Means placing the animals in the area of the explosion damaging factors include lattice cell that is located in low pressure chamber. Placing animals within the device (low pressure chamber) prevents obtaining state model (local impact of air shock wave to the appropriate part of the body, the dynamic change of parameters of air shock wave playback speed impact) making it impossible to further study the ASW impact the dynamics, because in experimental animals has generally shock wave to the entire body, affecting all organs and body systems. Taking into account the above-mentioned disadvantages of placing animals outside shock tube is the most peculiar study aimed to examine, for example, the primary mechanism of injury and can be made by standard biological object position in the study of the impact shock or blast wave.

Taking into account the relevance of research, we have developed a device for generating air shock wave (Figure 1). Prototypes following describes devices and methods are experimental models of brain trauma $[26,27,28]$. The design of the device consists of two hollow steel cylinders, which are mounted between the solenoid valve. Short cylinder (pressure chamber) contains two technological threaded holes, for fixing the pressure gauge that registers pressure injection and air mixture. Long cylinder (low pressure chamber) with a free end hole has a threaded hole technology for measuring dynamic pressure sensor. The free end of a single camera closed a rubber diaphragm, a fixed circular metal clamp. The whole construction is fixed on three metal supports. Two related valve cylinders with threaded connections. Supply air mixture in the chamber pressure is by forcing air through the hose using a compressor. Electromagnetic valve and compressor with electric power from a standard electrical outlet.

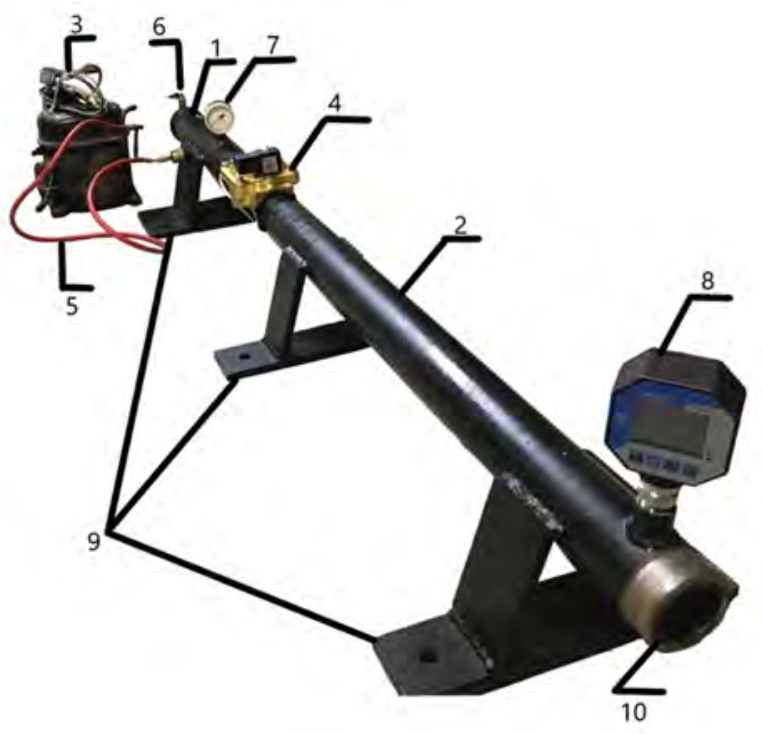

Fig. 1. Compressed air driven shock tube

Notes: 1. High pressure camera; 2. Low pressure camera; 3. Compressor; 4. Solenoid valve; 5 . Hose for air mixture supply; 6 . Overpressure relief valve; 7. Pressure gauge for static pressure measurement; 8. Pressure gauge for measuring excess pressure; 9. Metal supports for fixing the shock pipe; 10. Diaphragm.

ASW reproduction occurs in two stages. The first step is pumping air mixture to the camera using a high-pressure compressor. Regulation corresponding pressure gauge readings provided by the assessment. The second stage consists of two phases, namely, in the first phase takes place opening solenoid valve (switching air mixture with a high-pressure chamber to chamber low pressure) in the second - the 
gap aperture free end camera low pressure fixation threshold gap using the high dynamic manometer.

Thus, the advantages of shock tube in studying the effect of blast on living objects are the following: it is possible to reproduce a wide range of pressure peak of the shock wave, modeling different conditions of posture and distance; the lack of need for special protective equipment for the researcher, and minimal jet effect play close to the real profile of the gas shock [29].

Conclusion. Summarizing the advantages and disadvantages of existing experimental models of explosion-induced injury should note the significant progress methodological and design approaches that allow to conduct comparative studies. But the lack of a standardized explosion-induced trauma valid models should be developed further processing methods for better play in vitro simulation of factors influence the explosion. The proposed model of explosion-induced trauma rules out a number of shortcomings inherent in some models and allows you to generate a certain range with minimal material costs quickly and in the laboratory without special training air blast with local action.

There is a necessity to join separate thoughts of known experts in the field of experimental medicine concerning explosion-induced brain trauma [30] for coordinated multidisciplinary research approach to address controversial issues, and contradictory experimental blast injury.

Prospects for further research. In further research it is planned to introduce this device to reproduce blast-induced trauma of individual organs and organ systems of varying severity, followed by disclosure of pathogenesis, determination of functional, pathomorphological and biochemical markers of damage at different times after injury.

\section{References}

1. Vojchenko VV, Kozlov SV, Tkachenko OV, Zubov OL. Identyfikacija bojeprypasiv do avtomatychnogo stankovogo granatometu AGS-17 za morfologichnym harakterom ushkodzhen' ta ulamkiv, vyluchenyh z trupiv pid chas sudovo-medychnoi' ekspertyzy [Identification of ammunition to the automatic easel grenade launcher AGS-17 due to the morphological nature of the ears and ulamkiv, the thugs from the corpses every hour of the ship's medical examination]. Sudovo-medychna ekspertyza. 2018; (1): 58-60. [Ukranian]

2. Mamedov ShM, Tkachenko OV, Kozlov SV, Vydysh KP, Kozlova JuV, Lysycja OC, et al. Patomorfologichni aspekty vybuhovoi' travmy (porivnjal'na harakterystyka ushkodzhen', sprychynenyh protypihotnymy ulamkovymy minamy OZM-72 ta MON-50) [Pathomorphological aspects of vibukhovoy injuries (a specific characteristic of the ears, caused by the opposite ulamkovy mines OZM-72 and MON-50)]. Sudovo-medychna ekspertyza. 2017; (1): 102-106. [Ukranian]

3. Kozlov SV, Tkachenko OV, Zrozhevs'kyj RS. Sudovo-medychna harakterystyka tilesnyh ushkodzhen' pry kontaktnomu vybuhu granaty F-1 [The ship-medical characteristic of the forest ears with the contact vibukh of the F-1 grenade]. Sudovo-medychna ekspertyza. 2016; (1): 78-80. [Ukranian]

4. Savchenko SV, Tkachenko OV, Sokoljuk VG, Kozlov SV. Sudovo-medichna harakteristika vibuhovoï travmi, zapodijanoï ulamkami granati RGD-5 [Ship-medical characteristic of vibukhovoy injuries, zapod_yanoy ulamki grenade RGD-5]. Sudovo-medychna ekspertyza. 2015; (1): 95-97. [Ukranian]

5. Danyljuk $\mathrm{O}$, Meghoo $\mathrm{C}$, Linchevskyy $\mathrm{O}$. Causes of death among seventy-four military casualties in the ukrainian armed conflict. Eur J Trauma Emerg Surg. 2019; 45(1): S171-S172. doi: 10.1007/s00068-019-01109-1

6. Ling G, Ecklund JM, Bandak FA. Brain injury from explosive blast: description and clinical management. Handbook of Clin Neurol. 2015; 127: 173-80. doi: 10.1016/B978-0-444-52892-6.00011-8

7. Horrocks C. Blast injuries: biophysics, pathophysiology and management principles. BMJ Military Health. 2001; 147: 28-40.

8. Campos-Pires R, Yonis A, Macdonald W, Harris K, Edge JC, Mahoney PF, et al. A novel in vitro model of blast traumatic brain injury. Journal of visualized experiments. 2018; 142. doi: 10.3791/58400

9. Mutafchiyski VM, Popivanov GI, Kjossev KC. Medical aspects of terrorist bombings - a focus on DCS and DCR. Military Med Res. 2014; 1: 13. doi: 10.1186/2054-9369-1-13.

10. Kawa L, Kamnaksh A, Long J, Arborelius UP, Hökfelt T, Agoston VD, et al. A comparative study of two blast-induced traumatic brain injury models: changes in monoamine and galanin systems following single and repeated exposure. Frontiers in neurology. 2018; 9: 479. doi: 10.3389/fneur.2018.00479

11. Shi QX, Chen B, Nie C, Zhao ZP, Zhang JH, Si SY, et al. A novel model of blast induced traumatic brain injury caused by compressed gas produced sustained cognitive deficits in rats: involvement of phosphorylation of tau at the Thr205 epitope. Brain Res Bull. 2020; 157: 149-161. doi: 10.1016/j.brainresbull.2020.02.002.

12. Garcia-Gonzalez D, Race NS, Voets NL, Jenkins DR, Sotiropoulos SN, Acosta G, et al. Cognition based bTBI mechanistic criteria; a tool for preventive and therapeutic innovations. Scientific Reports. 2018; 8: 10273. doi: 10.1038/s41598-018-28271-7

13. Cernak I, Noble-Haeusslein LJ. Traumatic brain injury: an overview of pathobiology with emphasis on military populations. J Cereb Blood Flow Metab. 2010; 30(2): 255-266. doi: 10.1038/jcbfm.2009.203 
14. Risling M, Davidsson J. Experimental animal models for studies on the mechanisms of blast-induced neurotrauma. Frontiers in Neurology. 2012; 3: 30. doi: 10.3389/fneur.2012.00030

15. VandeVord PJ, Leonardi ADC, Ritzel D. Bridging the gap of standardized animals models for blast neurotrauma: methodology for appropriate experimental testing. Methods Mol Biol. 2016; 1462: 101-118. doi: 10.1007/978-14939-3816-2_7

16. Risling M, Davidsson J. Experimental animal models for studies on the mechanisms of blast-induced neurotrauma. Frontiers in neurology. 2012; 3: 30. doi: 10.3389/fneur.2012.00030

17. Turner RC, Naser ZJ, Logsdon AF, DiPasquale KH, Jackson GJ, Robson MJ, et al. Modeling clinically relevant blast parameters based on scaling principles produces functional \& histological deficits in rats. Experimental Neurology. 2013; 248: 520-529. doi: 10.1016/j.expneurol.2013.07.008

18. Bailey ZS, Hubbard WB, VandeVord PJ. Cellular mechanisms and behavioral outcomes in blast-induced neurotrauma: comparing experimental setups. injury models of the central nervous system. In: Methods in Molecular Biology. NY; Humana Press; 2016. 1462 p.

19. Jaiswal S, Knutsen AK, Wilson CM, Fu AH, Tucker LB, Kim Y, et al. Mild traumatic brain injury induced by primary blast overpressure produces dynamic regional changes in [18F]FDG uptake. Brain Research. 2019: 1723. doi: 10.1016/j.brainres.2019.146400

20. Badea A, Kamnaksh A, Anderson RJ, Calabrese E, Long JB, Agoston DV. Repeated mild blast exposure in young adult rats results in dynamic and persistent microstructural changes in the brain. Neurolmage Clinical. 2018; 18: 60-73. doi: 10.1016/j.nicl.2018.01.007

21. Chandra N, Sundaramurthy A, Kobeissy FH. Acute pathophysiology of blast injury-from biomechanics to experiments and computations: implications on head and polytrauma. In: Brain neurotrauma: molecular, neuropsychological, and rehabilitation aspects. Boca Raton (FL): CRC Press/Taylor \& Francis; 2015. Chapter 18.

22. Divani AA, Murphy AJ, Meints J, Sadeghi-Bazargani H, Nordberg J, Monga M, et al. A novel preclinical model of moderate primary blast-induced traumatic brain injury. Journal of Neurotrauma. 2015; 1109-1116. doi: 10.1089/ neu.2014.3686

23. Tong C, Liu Y, Zhang Y, Cong P, Shi X, Liu Y, et al. Shock waves increase pulmonary vascular leakage, inflammation, oxidative stress, and apoptosis in a mouse model. Experimental biology and medicine. 2018; 243(11): 934-944. doi: 10.1177/1535370218784539

24. Swietek B, Skotak M, Chandra N, Pfister BJ. Characterization of a controlled shock wave delivered by a pneumatic table-top gas driven shock tube. Rev Sci Instrum. 2019; 90(7): 075116. doi: 10.1063/1.5099633

25. Rubovitch V, Ten-Bosch M, Zohar O, Harrison CR, Tempel-Brami C, Stein E, et al. A mouse model of blastinduced mild traumatic brain injury. Exp Neurol. 2011; 232(2): 280-9. doi: 10.1016/j.expneurol.2011.09.018

26. Clemedson CJ, Criborn CO. A detonation chamber for physiological blast research. J Aviat Med. 1955; 26: 373381.

27. Cernak I, Merkle AC, Koliatsos VE, Bilik JM, Luong QT, Mahota TM, et al. The pathobiology of blast injuries and blast-induced neurotrauma as identified using a new experimental model of injury in mice. Neurobiol Dis. 2011; 41(2): 538-51. doi: 10.1016/j.nbd.2010.10.025

28. Zhou Y, Wen LL, Wang HD, Zhou XM, Fang J, Zhu JH, et al. Blast-induced traumatic brain injury triggered by moderate intensity shock wave using a modified experimental model of injury in mice. Chin Med J. 2018; 131(20): 2447-2460. doi: 10.4103/0366-6999.243558

29. Nguyen T, Pearce AP, Carpanen D, Sory D, Grigoriadis, Newell N, et al. Experimental platforms to study blast injury. BMJ Military Health. 2019; 165: 33-37. doi: 10.1136/jramc-2018-000966

30. Cernak I. Blast-induced neurotrauma models and their requirements. Front Neurol. 2014; 5: 128. doi: 10.3389/ fneur.2014.00128

\section{УДК 612.12-001.45:340.624 \\ РЕТРОСПЕКТИВНИЙ АНАЛІЗ ТА СУЧАСНИЙ СТАН ЕКСПЕРИМЕНТАЛЬНИХ МОДЕЛЕЙ ВИБУХО-ІНДУКОВАНОЇ ТРАВМИ \\ Козлова Ю. В., Кошарний А. В., Корзаченко М. А., Китова І. В.}

Резюме. Проблема вибухо-індукованої травми на жаль не втрачає своєї актуальності, адже озброєні конфлікти з використанням вибухівки відбуваються в різних країнах світу. Але патогенез, діагностика, лікування та реабілітація посттравматичних вибухо-індукованих розладів гострих та віддалених, а саме, нейродегенеративних ускладнень, психосоматичних станів, когнітивних порушень, ускладнень з боку сенсорних систем, легень, кишківника, паренхіматозних органів черевної порожнини на даний час до кінця не вивчені та достатньо не зрозумілі для адекватної терапії. На теперішній час дані щодо механізмів ушкодження $є$ поверховими, не розроблено чітких критеріїв оцінки функціональних, морфологічних та біохімічних змін на тлі вибухо-індукованої травми. 
Ретроспективний аналіз літературних джерел щодо експериментального відтворення вибухо-індукованої травми показав високу зацікавленість широкого кола науковців в останнє десятиріччя. Якісне дослідження наукових публікацій показало широкий спектр фізичних характеристик експериментальної ударної хвилі, способів та пристроїв для моделювання вибухо-індукованої травми. Відсутність стандартизованої моделі вибухо-індукованої травми з максимально наближеними до реальних обставин характеристиками створює умови для впровадження власних пропозицій. В цій роботі представлена апробована модифікована експериментальна модель для відтворення в лабораторних умовах повітряної ударної хвилі, що надає можливості дослідити особливості перебігу вибухо-індукованої травми різних органів та систем органів в різні періоди після ушкодження.

Ключові слова: вибухо-індукована травма, ударна труба, експериментальна модель.

\section{УДК 612.12-001.45:340.624}

\section{РЕТРОСПЕКТИВНЫЙ АНАЛИЗ И СОВРЕМЕННОЕ СОСТОЯНИЕ ЭКСПЕРИМЕНТАЛЬНЫХ МОДЕЛЕЙ ВЗРЫВНОЙ ТРАВМЫ \\ Козлова Ю. В., Кошарный А. В., Корзаченко М. А., Китова И. В.}

Резюме. Проблема взрывной травмы, к сожалению, не теряет своей актуальности, ведь вооруженные конфликты с использованием взрывчатки происходят в разных странах мира. Но патогенез, диагностика, лечение и реабилитация посттравматических расстройств острых и отдаленных, а именно, нейродегенеративных осложнений, психосоматических состояний, когнитивных нарушений, осложнений со стороны сенсорных систем, легких, кишечника, паренхиматозных органов брюшной полости в настоящее время до конца не изучены и достаточно не понятны для адекватной терапии. В настоящее время данные о механизмах повреждения являются поверхностными, не разработаны четкие критерии оценки функциональных, морфологических и биохимических изменений на фоне взрывной травмы.

Ретроспективный анализ литературных источников об экспериментальном воспроизведении взрывной травмы показал высокую заинтересованность большого круга ученых в последнее десятилетие. Качественное исследование научных публикаций показал широкий спектр физических характеристик экспериментальной ударной волны, способов и устройств для моделирования взрывной травмы. Отсутствие стандартизированной модели взрывной травмы с максимально приближенными к реальным обстоятельств характеристиками создает условия для внедрения собственных предложений. В этой работе представлена апробированная модифицированная экспериментальная модель для воспроизведения в лабораторных условиях воздушной ударной волны, что дает возможность исследовать особенности течения взрывной травмы различных органов и систем органов в различные периоды после повреждения.

Ключевые слова: взрывная травма, ударная труба, экспериментальная модель.

The authors of this study confirm that the research and publication of the results were not associated with any conflicts regarding commercial or financial relations, relations with organizations and/or individuals who may have been related to the study, and interrelations of coauthors of the article. 